\title{
Article \\ Physical, Chemical, and Microbiological Characterization of Kettara Mine Tailings, Morocco
}

\author{
Leila Benidire $^{1,2}$, Sofia I. A. Pereira ${ }^{3}{ }^{(\mathbb{C}}$, Souad Loqman ${ }^{4}{ }^{(0}$, Paula M. L. Castro ${ }^{3}$ and Ali Boularbah ${ }^{1,5, *}$ \\ 1 Laboratoire de Bioressources et Sécurité Sanitaire des Aliments, Faculté des Sciences et Techniques, Université \\ Cadi Ayyad, Boulevard Abdelkrim Khattabi, BP 549, Marrakech 40000, Morocco; leila.benidire@edu.uca.ma \\ 2 Ecole Supérieure de Technologie, Université Cadi Ayyad, El Kelâa des Sraghna, Marrakech 40000, Morocco \\ 3 CBQF-Centro de Biotecnologia e Química Fina, Laboratório Associado, Escola Superior de Biotecnologia, \\ Universidade Católica Portuguesa, Rua Diogo Botelho 1327, 4169-005 Porto, Portugal; \\ sapereira@ucp.pt (S.I.A.P.); plcastro@ucp.pt (P.M.L.C.) \\ 4 Laboratory of Microbiology and Virology, Faculty of Medicine and Pharmacy, Cadi Ayyad University, \\ P.O. Box 7010, Marrakesh 40000, Morocco; s.loqman@uca.ma \\ 5 Center of Excellence for Soil and Africa Research in Africa, Agrobio Sciences Program, Université Mohammed \\ VI Polytechnique (UM6P), Benguerir 43150, Morocco \\ * Correspondence: a.boularbah@uca.ma
}

check for updates

Citation: Benidire, L.; Pereira, S.I.A.; Loqman, S.; Castro, P.M.L.; Boularbah, A. Physical, Chemical, and Microbiological Characterization of Kettara Mine Tailings, Morocco. Soil Syst. 2022, 6, 23. https:// doi.org/10.3390/soilsystems6010023

Received: 20 November 2021

Accepted: 15 February 2022

Published: 23 February 2022

Publisher's Note: MDPI stays neutral with regard to jurisdictional claims in published maps and institutional affiliations.

Copyright: () 2022 by the authors. Licensee MDPI, Basel, Switzerland. This article is an open access article distributed under the terms and conditions of the Creative Commons Attribution (CC BY) license (https:// creativecommons.org/licenses/by/ $4.0 /)$.

\begin{abstract}
The mining industry is of major importance to Morocco's economy. However, the abandoned pyritic mines are a source of potentially toxic elements that can cause the disruption of the surrounding ecosystems, constituting a huge threat to wellbeing and human health. The present study aimed to analyze the physical and chemical characteristics of different types of tailings and to investigate the microbial populations of acidophilic bacteria involved in the oxidation of pyrite. Coarse and fine tailings collected from different zones of the mine (dike and pond) at two different depths (oxidized and non-oxidized residues) were analyzed for their $\mathrm{pH}$, electrical conductivity, total organic carbon, total nitrogen, available $\mathrm{P}$, major elements, and pseudo-total metal concentrations. The abundance of acidophilic bacteria was determined, and some acidophilic bacterial strains were isolated and tested for their metal tolerance. Tailings showed a $\mathrm{pH} \approx 2$, very low nutritional content, and high concentrations of $\mathrm{Cu}, \mathrm{As}, \mathrm{Zn}$, and $\mathrm{Pb}$, which were higher in the non-oxidized samples. The microbial counts of iron- and sulfur-oxidizing bacteria were higher than heterotrophic bacteria, with the highest numbers detected in the oxidized fine tailings. The five acidophilic bacteria isolated from the tailings were affiliated to genera Alicyclobacillus and Sulfobacillus, commonly found in this kind of environment.
\end{abstract}

Keywords: acidophilic bacteria; acid mine drainage; metals; runoff waters

\section{Introduction}

Soil is a dynamic system that provides a myriad of ecosystems services divided into four main categories: provisioning, supporting, regulating, and cultural services [1,2]. Ecosystems services ensure human well-being and rely on the interaction between the different soil components, including mineral and organic fractions, pore air, etc., and living organisms such as bacteria, fungi, protozoa, and macroinvertebrates [3].

The mining sector underpins the economic development of many countries [4]; however, intensive mining activity often leads to the disruption of natural ecosystems, causing high biodiversity losses [5-7].

Mining processes such as grinding, washing, and ore concentration, generate large amounts of waste rocks and tailings, which are heavily contaminated with metals easily dispersed into mine surrounding areas by wind and water erosion [8-12]. Mining wastes containing metal sulfide minerals, such as pyrite and pyrrhotite, are a global concern as they can suffer chemical and biological oxidation leading to acid mining drainage (AMD) [13,14]. 
These highly acid streams will contribute to amplifying the dispersion of metallic pollutants, causing the subsequent contamination of underground and surface water and deterioration of fertile soil layers [15].

Despite the harsh conditions for microbial growth, several autotrophic and heterotrophic bacterial communities colonize mine tailings and AMD [16-18]. The role of acidophilic bacteria in sulfur-containing mining wastes is controversial as sulfur- and ironoxidizing bacteria can promote acid generation and metal mobilization, while heterotrophic and sulfur- and iron-reducing bacterial communities can be applied in bioremediation approaches to reduce the impact of mining activities on ecosystems [17,19]. Microbial-based strategies to reclaim mining areas encompass several mechanisms, including the formation of soluble metal chelates by the release of organic acids (bioleaching), enzyme-catalyzed reactions, mineralization, absorption of contaminants and/or sorption on the surface of cells, and extracellular sequestration [20].

The environmental damage caused by sulfide-containing mining wastes urge remediation strategies tailored for these degraded areas. In the present study, we aimed at evaluating the physical, chemical, and microbiological properties of coarse and fine tailings recovered from non-oxidized and oxidized zones in an abandoned pyrrhotite mine. We also intended to isolate and identify metal-tolerant acidophilic bacteria present in tailings for further application in bioremediation strategies.

\section{Materials and Methods}

\subsection{Area of Study and Sampling}

The Kettara mine is in the northeast region of Morocco in the central area of Jebilet massif, approximately $35 \mathrm{~km}$ from Marrakech city. This mine was heavily exploited from 1964 to 1981, with a production of more than 5.2 million tons of pyrrhotite enriched with high levels of sulfide minerals (16-145 $\mathrm{mg} \mathrm{g}^{-1}$ of sulfur) [21]. The extraction of pyrrhotite generated high amounts of tailings which were deposited over an area of approximately 16 ha $[8,11]$. The Kettara mine tailings can be classified as coarse (fine gravel)_deposited in the 15-m high dike and in 1-m high tailings piles; and fine (silt)_deposited in the tailings pond [21]. The climate in the Kettara region is arid, with an average annual rainfall and temperature of $300 \mathrm{~mm}$ and $20^{\circ} \mathrm{C}$, respectively. The area in the vicinity of the mining dump is mainly colonized by heterogeneous herbaceous vegetation with scarce patches of spontaneous plants [22].

Composite samples of coarse and fine tailings were collected from the Kettara mine (Figure 1). Two samples were taken from the dike $\left(31^{\circ} 52^{\prime} 25.4^{\prime \prime} \mathrm{N}, 8^{\circ} 10^{\prime} 43.9^{\prime \prime} \mathrm{W}\right)$ consisting of oxidized and non-oxidized coarse tailings (OC and NOC, respectively), while the other two samples were collected from the tailings pond $\left(31^{\circ} 52^{\prime} 25.9^{\prime \prime} \mathrm{N}, 8^{\circ} 10^{\prime} 41.8^{\prime \prime} \mathrm{W}\right)$ consisting of oxidized and non-oxidized fine tailings (OF and NOF, respectively). The degree of oxidation was evaluated visually according to Hakkou et al. [21] who also confirmed it by mineralogical analysis. The oxidized layer was characterized by yellow to orange color, while the non-oxidized layer had a blue-grey color for fine tailings and a brown-red color for coarse tailings. The oxidized layer thickness varied between 5 and $15 \mathrm{~cm}$. Two samples of runoff water (RW1, RW2) were also collected from the tailings pond during the rainy season. 

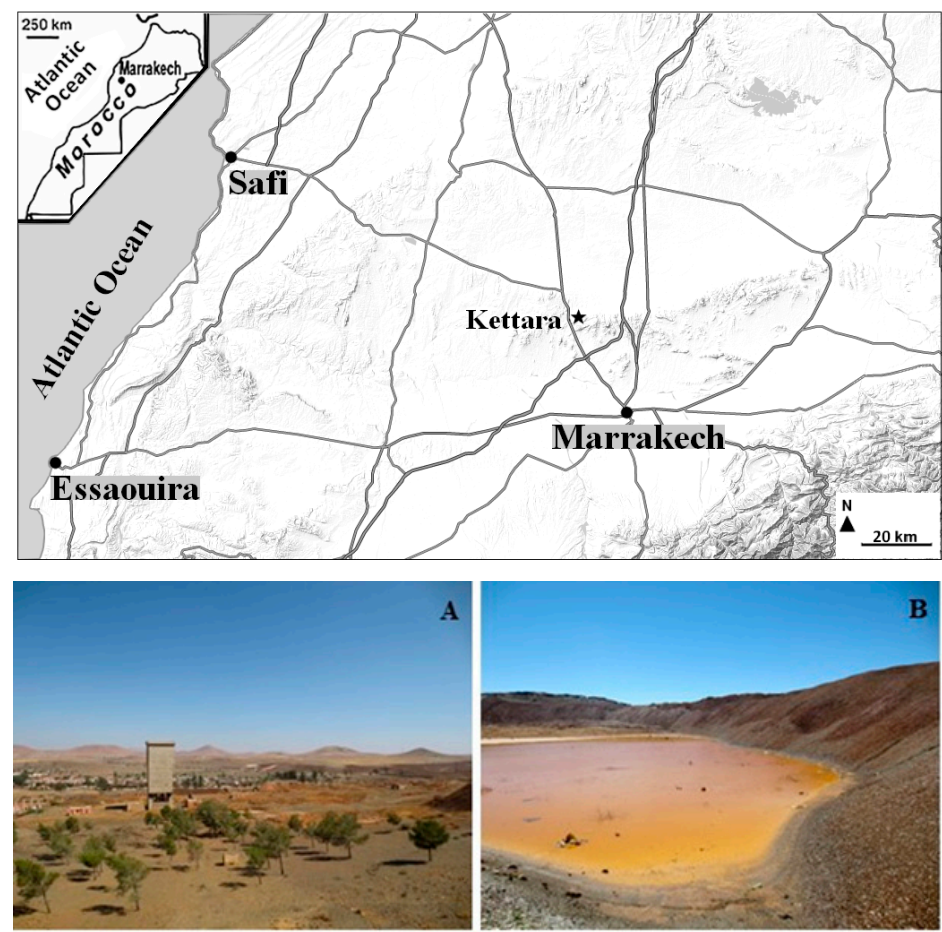

C
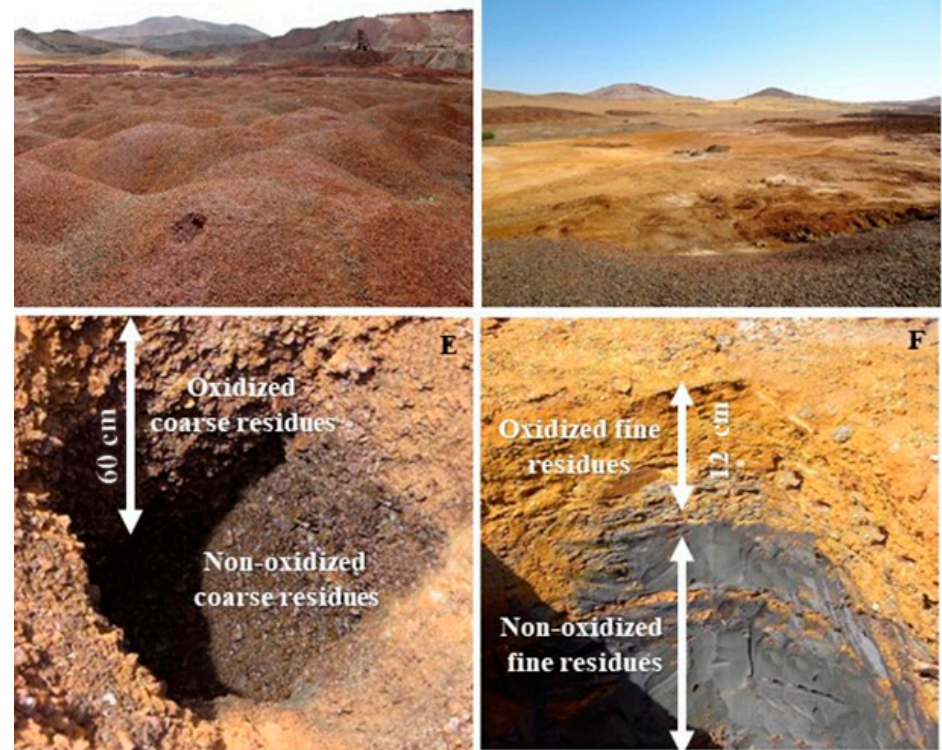

Figure 1. Location and panoramic view of Kettara mine (A); AMD effluent (B); Coarse tailings (C,E); Fine tailings (D,F).

The samples from coarse and fine tailings were collected using a thoroughly cleaned and disinfected shovel. The samples were then placed in sterile plastic bags for physical, chemical, and microbiological analysis. The runoff samples were collected in sterile polypropylene screw vials for chemical characterization. All samples were transported to the laboratory in an icebox and stored at $4{ }^{\circ} \mathrm{C}$ overnight. Bacterial isolation and enumeration were carried out within 48 to 72 h of collection.

Prior to physical and chemical analyses, the tailings samples were weighed and dried for $48 \mathrm{~h}$ at $45^{\circ} \mathrm{C}$. The samples were subsequently weighed, and the water content was calculated. Then, the samples were homogenized, sieved through a $2 \mathrm{~mm}$ mesh, and stored in sealed plastic bags until analysis. The $\mathrm{pH}$ and electrical conductivity were directly measured in runoff water in situ using a multi-parameter water quality analyzer (Orion 4-Star Portable pH/Conductivity Meter from Thermo Fisher Scientific, Waltham, MA, 
USA). For tailings, the measurements were made in the laboratory in aqueous solutions $(1: 2.5$ and $1: 5 w / v)$. The total organic carbon was determined by the dichromate oxidation method [23], while the total nitrogen and the available phosphorus were determined by Kjeldahl and molybdenum blue methods [24], respectively.

\subsection{Multi-Element Analysis}

The tailings samples were digested at high temperature using a mixture of $\mathrm{HNO}_{3} / \mathrm{Br}_{2} /$ $\mathrm{HF} / \mathrm{HCl}(2: 1: 1: 1)$ as described by [25]. Briefly, $0.5 \mathrm{~g}$ of dry sample (particle size $<2 \mathrm{~mm}$ ) in a borosilicate flask was first mixed with $\mathrm{HNO}_{3}$ and gently boiled on a hot plate at $90{ }^{\circ} \mathrm{C}$ until a clear solution was obtained. Then, liquid bromine $\left(\mathrm{Br}_{2}\right), \mathrm{HF}$, and $\mathrm{HCl}$ were successively added, and the mixture was heated $\left(100\right.$ to $\left.200{ }^{\circ} \mathrm{C}\right)$ until total digestion. The flask content was then evaporated to dryness and the extract was resuspended in ultrapure acidified water ( $2 \%$ nitric acid), filtered $(<0.45 \mu \mathrm{m}$, ashless filter paper), and stored in polyethylene containers until analysis. The following elements $\mathrm{Al}, \mathrm{As}, \mathrm{Ba}, \mathrm{B}, \mathrm{Ca}, \mathrm{Co}, \mathrm{Cr}, \mathrm{Cu}, \mathrm{Fe}, \mathrm{Mg}, \mathrm{Mn}$, $\mathrm{Ni}, \mathrm{Pb}, \mathrm{S}, \mathrm{Ti}$, and $\mathrm{Zn}$ were measured in acid digested samples using inductively coupled plasma-atomic emission spectroscopy (ICP-AES, Perkin Elmer Optima 3000, Norwalk, CT, USA).

The concentrations of $\mathrm{Cu}, \mathrm{Zn}$, and $\mathrm{Pb}$ in runoff water were determined by flame atomic absorption spectrometry (FAAS, Model Perkin Elmer AAnalyst 400, Waltham, MA USA). In prior analysis, water samples were filtered with an ashless filter paper to remove any particles and then acidified with nitric acid.

\subsection{Enumeration of Indigenous Acidophilic Bacteria of Mine Tailings}

The abundance of indigenous acidophilic bacteria including iron-oxidizing bacteria (IOB), sulfur-oxidizing bacteria (SOB), and heterotrophic acidophilic bacteria (HAB) was determined in mine residues using the most probable number (MPN) method described by [26]. Briefly, 3 tubes MPN series with different growth media $(\mathrm{pH}=2.5)$ were inoculated with a bacterial suspension prepared from tailing samples and their dilutions. The bacterial growth after an incubation period of 15 days at $30{ }^{\circ} \mathrm{C}$ with agitation $(150 \mathrm{rpm})$ was assessed. The number of total bacteria present was then estimated by counting the number of tubes giving a positive reaction (i.e., presence of turbidity) and comparing the pattern of positive results with Mac Grady tables. The iron-oxidizing acidophiles were quantified in TK liquid medium (per liter: $33.4 \mathrm{~g}$ of $\mathrm{FeSO}_{4} \cdot 7 \mathrm{H}_{2} \mathrm{O} ; 0.4 \mathrm{~g}$ of $\left(\mathrm{NH}_{4}\right)_{2} \mathrm{SO}_{4} ; 0.4 \mathrm{~g}$ of $\mathrm{MgSO}_{4} \cdot 7 \mathrm{H}_{2} \mathrm{O}$, and $0.4 \mathrm{~g}$ of $\mathrm{K}_{2} \mathrm{HPO}_{4}$ ) [27]. Sulfur-oxidizing acidophiles were quantified using elemental sulfur or thiosulfate as a substrate for bacteria in modified 9KS medium (per liter: $3 \mathrm{~g}$ of $\left(\mathrm{NH}_{4}\right)_{2} \mathrm{SO}_{4} ; 0.5 \mathrm{~g}$ of $\mathrm{MgSO}_{4} 7 \mathrm{H}_{2} \mathrm{O} ; 0.5 \mathrm{~g}$ of $\mathrm{K}_{2} \mathrm{HPO}_{4} ; 0.1 \mathrm{~g}$ of $\mathrm{KCl} ; 0.012 \mathrm{~g}$ of $\mathrm{Ca}\left(\mathrm{NO}_{3}\right)_{2}$; and $1 \%(w / v)$ of elemental sulfur added) [28], while Luria-Bertani (LB) medium (per liter: $10 \mathrm{~g}$ of peptone; $5 \mathrm{~g}$ of yeast extract and $10 \mathrm{~g}$ of $\mathrm{NaCl}$ ) was used for the quantification of $\mathrm{HAB}$. $\mathrm{A}$ tube was considered positive in LB medium when turbidity in the culture medium was observed. For the TK medium, a positive result was estimated when the medium became orange, indicating the production of jarosite as a result of the oxidation of iron sulphates by bacteria [29]. Concerning acidophilic sulfur-oxidizing cultures, the tubes were found to be positive if rod-shaped cells were visible under a microscope [29].

\subsection{Isolation and Identification of Acidophilic Bacteria}

\subsubsection{Isolation}

The acidophilic bacteria were isolated from oxidized and non-oxidized Kettara mine tailings and from runoff water in contact with the fine tailings using a pre-enrichment culture in Tryptone-Soy Broth (TSB; Biokar Diagnostics, Allonne, France) supplemented with iron (FeTSB; per liter: $0.25 \mathrm{~g}$ of TSB, $1.25 \mathrm{~g}$ of $\left(\mathrm{NH}_{4}\right)_{2} \mathrm{SO}_{4}, 0.5 \mathrm{~g}$ of $\mathrm{MgSO}_{4}, 25 \mathrm{mM}$ $\mathrm{FeSO}_{4}$ ). This medium was used as it allows the growth of iron- and sulfur-oxidizing bacteria and heterotrophic acidophilic bacteria [30]. For this purpose, $1 \mathrm{~g}$ of tailings (fine and coarse oxidized and non-oxidized) or $1 \mathrm{~mL}$ of runoff water was inoculated separately in $250 \mathrm{~mL}$ Erlenmeyer flasks containing $100 \mathrm{~mL}$ of FeTSB. All cultures were then incubated with 
agitation (150 rpm) at $30{ }^{\circ} \mathrm{C}$ for about 15 days. Five cycles of successive subcultures on liquid media have been carried out since successive subcultures of acidophilic bacteria strains under the same conditions help to obtain better cell growth in a solid medium. Periodically, microscopic observations were made to confirm the presence of microorganisms. Then, the cultures were transferred for FeTSB medium supplemented with agar $\left(15 \mathrm{~g} \mathrm{~L}^{-1}\right)$ and colonies isolated according to their different morphologies.

\subsubsection{DNA Extraction}

The genomic DNA of each isolate was extracted using the DNeasy UltraClean ${ }^{\circledR}$ Microbial Kit, Qiagen, Germantown, MD, USA, according to the protocol established by the manufacturer. The extraction procedure was performed using bacterial pellets obtained after centrifugation at $13,000 \times g$ for $5 \mathrm{~min}$ of $2 \mathrm{~mL}$ of a bacterial culture grown for 15 days in FeTSB medium.

\subsubsection{Amplification of the $16 \mathrm{~S}$ rRNA Gene and Sequencing}

The 16S rDNA amplification was performed with universal primers 27F (50-GAGTTTGATCCTGGCTCAG-30) and 1492R (5'-ACCTTGTTACGACTT-3') (MWG-Biotech, Huntsville, AL, USA). The PCR amplifications were performed in a $50 \mu \mathrm{L}$ reaction mix containing: $1 \times$ buffer (Promega, Madison, WI, USA), $2.5 \mathrm{mM} \mathrm{MgCl}_{2}, 0.2 \mathrm{mM}$ dNTPs (Bioron), $1 \mu \mathrm{M}$ of each primer, $1.5 \mu \mathrm{L}$ of Dimethylsulfoxide, 0.5 U Taq polymerase (GoTaq, Promega, Madison, WI, USA), and $2 \mu \mathrm{L}$ of DNA. The amplifications were performed in a Bio-Rad MJ Mini thermal cycler according to the following program: an initial denaturation step at $94{ }^{\circ} \mathrm{C}$ for $5 \mathrm{~min}$, followed by 30 cycles of $94{ }^{\circ} \mathrm{C}$ for $1 \mathrm{~min}, 52{ }^{\circ} \mathrm{C}$ for $1 \mathrm{~min}$, and $72{ }^{\circ} \mathrm{C}$ for $1 \mathrm{~min}$, with a final extension at $72{ }^{\circ} \mathrm{C}$ for $10 \mathrm{~min}$. A negative control was systematically included in each series of reactions to ensure the sterility of the different reagents used. PCR products were purified using the GRS PCR \& Gel Band Purification kit (GRISP, Porto, Portugal) according to the manufacturer's recommendations and sent to Macrogen Inc. (Amsterdam, The Netherlands) for sequencing. The nucleotide sequences were edited using the BioEdit software (version 7.0) and a similarity search was performed using the BLAST program (www.ncbi.nlm.nih.gov/blast (accessed on 10 November 2011)). Phylogenetic trees were constructed by the maximum likelihood method using MEGA software (version 6.0) [31]. The 16S rRNA sequences of acidophilic bacteria were deposited in GenBank under the accession numbers OL456194 to OL456197.

\subsection{Metal Tolerance of Bacterial Isolates}

The tolerance of bacterial isolates to $\mathrm{Cu}\left(\mathrm{CuSO}_{4} \cdot 5 \mathrm{H}_{2} \mathrm{O}\right), \mathrm{Zn}\left(\mathrm{ZnSO}_{4} \cdot 7 \mathrm{H}_{2} \mathrm{O}\right)$, and Co $\left(\mathrm{Co}\left(\mathrm{NO}_{3}\right)_{2}\right)$ was achieved by determining the minimum inhibitory concentration (MIC) in FeTSB medium supplemented with six concentrations of different metals. The concentrations varied between 317.73 to $7943.25 \mathrm{mg} \mathrm{L}^{-1}$ for $\mathrm{Cu}$, from 3269 to $65,380 \mathrm{mg} \mathrm{L}^{-1}$ for $\mathrm{Zn}$, and from 589.332 to $8250.648 \mathrm{mg} \mathrm{L}^{-1}$ for Co. Controls without metal but with bacterial inocula were also performed. All experiments were performed in triplicate. Isolates showing growth after 15 days of incubation at $30{ }^{\circ} \mathrm{C}$ were considered tolerant to the metal concentration tested.

\section{Results}

\subsection{Physical and Chemical Characterization of Mine Tailings}

The mine tailings showed a very acidic $\mathrm{pH}$, ranging from 2.06 to 3.51 for fine residues and 2.40 to 2.80 for coarse residues. The non-oxidized samples showed lower $\mathrm{pH}$ than oxidized for both types of residues (Table 1). The mine tailings showed high EC (1.93-3.01 $\left.\mathrm{mS} \mathrm{cm}^{-1}\right)$, with the highest values being recorded in the oxidized samples $\left(2.45\right.$ and $3.01 \mathrm{mS} \mathrm{cm}^{-1}$ for fine and coarse residues, respectively). The Kettara mine tailings had very low nutrient content with TOC and P Olsen levels not exceeding 3.40 and $0.06 \mathrm{mg} \mathrm{g}^{-1}$, respectively. The $\mathrm{TN}$ was below the limit of detection in most samples. 
Table 1. Physical and chemical properties of oxidized and non-oxidized fine and coarse tailings of Kettara Mine.

\begin{tabular}{ccccc}
\hline & \multicolumn{2}{c}{ Fine Residues } & \multicolumn{2}{c}{ Coarse Residues } \\
\cline { 2 - 5 } & OF & NOF & OC & NOC \\
\hline $\mathrm{pH}$ & 3.51 & 2.06 & 2.80 & 2.40 \\
$\mathrm{EC}\left(\mathrm{mS} \mathrm{cm}^{-1}\right)$ & 2.45 & 1.93 & 3.01 & 2.30 \\
$\left.\mathrm{TOC}^{-1} \mathrm{mg} \mathrm{g}^{-1}\right)$ & 1.90 & 1.40 & 2.00 & 1.30 \\
$\mathrm{TN}\left(\mathrm{mg} \mathrm{g}^{-1}\right)$ & 0.40 & $<\mathrm{dL}$ & $<\mathrm{dL}$ & $<\mathrm{dL}$ \\
$\left.\mathrm{C} / \mathrm{N}^{-1}\right)$ & 8.25 & $\mathrm{nd}$ & $\mathrm{nd}$ & $\mathrm{nd}$ \\
P Olsen $\left(\mathrm{mg} \mathrm{g}^{-1}\right)$ & 0.05 & 0.06 & 0.01 & 0.01 \\
\hline
\end{tabular}

<dL: below detection limit; nd: not determined; EC: Electrical conductivity; TOC: Total organic carbon; TN: Total nitrogen; P Olsen: Available phosphorus. OF: oxidized fine residues; NOF: non-oxidized fine residues; OC: oxidized coarse residues; NOC: non-oxidized coarse residues.

The concentration of major elements and trace metals in oxidized and non-oxidized residues is shown in Table 2. The major elements found in the different mining residues were $\mathrm{Fe}, \mathrm{Mg}, \mathrm{Al}, \mathrm{S}, \mathrm{Ca}$, and $\mathrm{Ti}$. Iron was the most abundant element reaching values of $45.0 \mathrm{mg} \mathrm{g}^{-1}$ in oxidized fine samples (OF) and 296.0 and $339.0 \mathrm{mg} \mathrm{g}^{-1}$ in oxidized (OC) and non-oxidized (NOC) coarse residues, respectively, followed by $\mathrm{Al}$ with levels varying between 11.2 and $77.2 \mathrm{mg} \mathrm{g}^{-1}$ in oxidized (OF) and non-oxidized fine residues (NOF), respectively. Sulfur was the third most abundant element varying between 20.8 and $37.9 \mathrm{mg} \mathrm{g}^{-1}$. The oxidized and non-oxidized samples showed similar contents of $\mathrm{S}$, however, coarse residues showed lower levels of $S$ than fine. The different types of mine tailings were also characterized by high amounts of $\mathrm{Mg}\left(12.6\right.$ to $\left.49.8 \mathrm{mg} \mathrm{g}^{-1}\right)$, while Ca levels were low, not exceeding $10.1 \mathrm{mg} \mathrm{g}^{-1}$. The tailings samples were mainly contaminated with $\mathrm{Cu}, \mathrm{Zn}, \mathrm{Pb}$, and As. The pseudo-total concentration of $\mathrm{Cu}$ in the different types of tailings were higher than those found for $\mathrm{Pb}, \mathrm{Zn}$, and As ranging from $0.65 \mathrm{mg} \mathrm{g}^{-1}$ in NOC and $1.89 \mathrm{mg} \mathrm{g}^{-1}$ in NOF samples. The $\mathrm{Pb}$ concentrations varied between $0.11 \mathrm{mg} \mathrm{g}^{-1}$ in fine residues (oxidized and non-oxidized) and 0.22 and $0.07 \mathrm{mg} \mathrm{g}^{-1}$ in oxidized and non-oxidized coarse residues, respectively. The pseudo-total $\mathrm{Zn}$ concentrations ranged from 0.05 to $0.57 \mathrm{mg} \mathrm{g}^{-1}$ with the highest concentration being recorded in non-oxidized fine residues (NOF), while the higher As concentrations were found in coarse residues $\left(0.14-0.16 \mathrm{mg} \mathrm{g}^{-1}\right)$.

Table 2. Major elements and trace elements content in oxidized and non-oxidized fine and coarse tailings of Kettara mine.

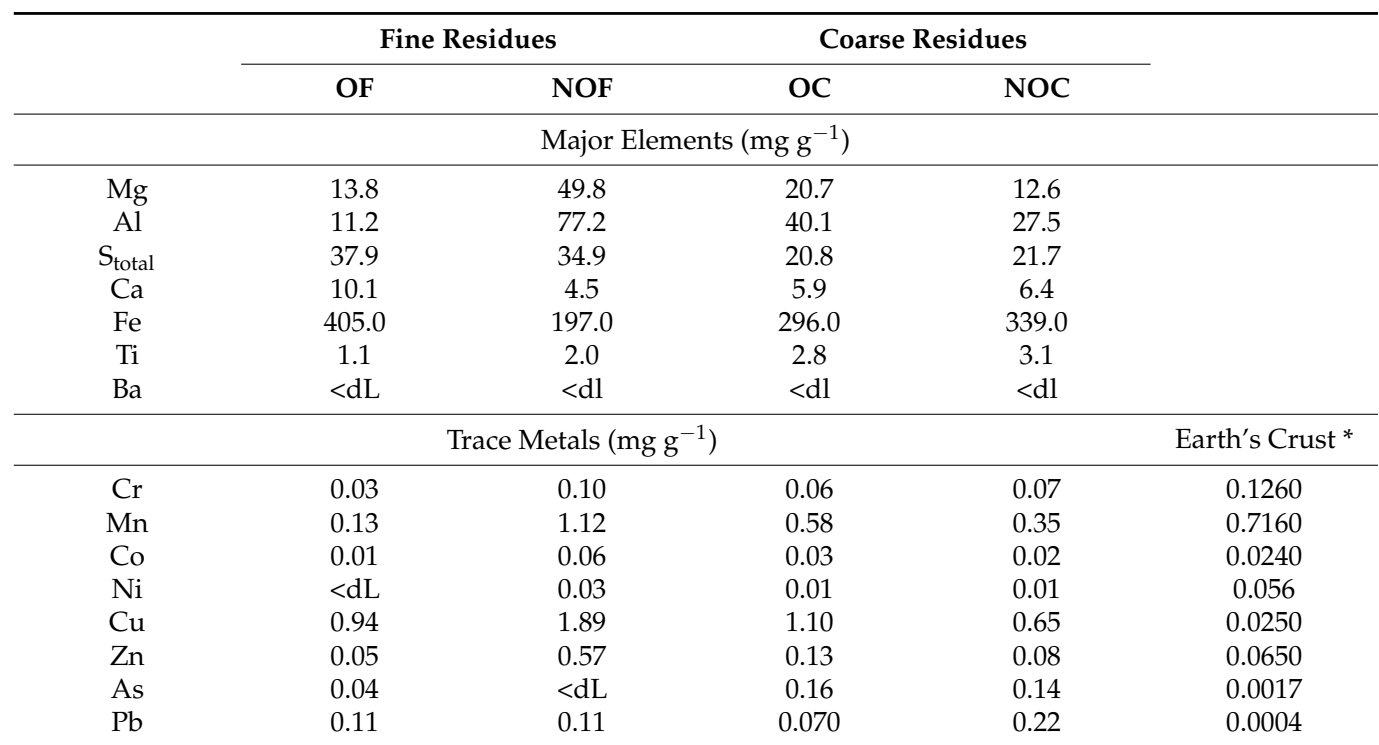

OF: oxidized fine residues; NOF: non-oxidized fine residues; OC: oxidized coarse residues; NOC: non-oxidized coarse residues; <dL: below detection limit; * Average levels in the earth's crust [32]. 
The physical and chemical properties of runoff water collected near the Kettara mine are summarized in Table 3. The results showed that runoff waters were characterized by very acidic $\mathrm{pH}(\approx 2)$ and moderate salinity $\left(\approx 7 \mathrm{mS} \mathrm{cm}^{-1}\right)$. The runoff water samples presented high concentrations of $\mathrm{Zn}, \mathrm{Cu}$, and $\mathrm{Pb}$, with the highest values being recorded in sample RW1 (45.81 $\mathrm{mg}$ of $\mathrm{Cu} \mathrm{L}^{-1}, 97.04 \mathrm{mg}$ of $\mathrm{Zn} \mathrm{L}^{-1}$ and $2.12 \mathrm{mg}$ of $\mathrm{Pb} \mathrm{L}^{-1}$ ).

Table 3. Values of $\mathrm{pH}$, electrical conductivity, and pseudo-total metal concentrations $(\mathrm{Zn}, \mathrm{Cu}$, and $\mathrm{Pb}$ ) in runoff waters collected in Kettara mine spoil.

\begin{tabular}{lccccc}
\hline & \multirow{2}{*}{$\mathbf{~}$} & $\mathbf{E C}$ & \multicolumn{3}{c}{ Trace Metals $\left(\mathbf{m g ~ L}^{-\mathbf{1})}\right.$} \\
\cline { 4 - 6 } & & $\left(\mathbf{m S ~ c m}^{-\mathbf{1}}\right)$ & $\mathbf{Z n}$ & $\mathbf{C u}$ & $\mathbf{P b}$ \\
\hline RW1 & 2.23 & 7.32 & 45.81 & 97.04 & 2.12 \\
RW2 & 2.19 & 6.81 & 25.42 & 68.02 & 1.63 \\
\hline
\end{tabular}

\subsection{Enumeration of $I O B, S O B$ and $H A B$}

The MPN of acidophilic bacteria in tailings and contaminated runoff waters collected in the Kettara mine are shown in Table 4. The number of cells of iron (IOB)- and sulfur (SOB)-oxidizing bacteria varied according to the type of tailing and the oxidation status. The IOB and SOB were more abundant (+2-3 log units) than heterotrophic bacteria. The highest counts of IBO, SBO, and HAB were detected in oxidized fine tailings $\left(6.5 \times 10^{5}\right.$, $5.9 \times 10^{5}, 3.1 \times 10^{2} \mathrm{CFU} \mathrm{g}^{-1}$ dry weight, respectively). In coarse residues, no meaningful differences were observed between oxidized and non-oxidized samples, except for IOB which were more abundant (+1 log unit) in oxidized residues.

Table 4. MPN-determined cell densities of iron-oxidizing (IOB), sulfur-oxidizing (SOB), and heterotrophic acidophilic (HAB) bacteria in residues (MPN g ${ }^{-1}$ ) and runoff waters $\left(\mathrm{MPN} \mathrm{ml}^{-1}\right)$ of Kettara mine.

\begin{tabular}{ccccccc}
\hline \multirow{2}{*}{ Samples } & \multicolumn{2}{c}{ Fine Residues } & \multicolumn{2}{c}{ Coarse Residues } & \multicolumn{2}{c}{ Runoff Water } \\
\cline { 2 - 7 } & OF & NOF & OC & NOC & RW1 & RW2 \\
\hline IOB & $6.5 \times 10^{5}$ & $4.8 \times 10^{5}$ & $4.3 \times 10^{5}$ & $8.9 \times 10^{4}$ & $9.9 \times 10^{5}$ & $8.6 \times 10^{5}$ \\
SOB & $5.9 \times 10^{5}$ & $7.3 \times 10^{4}$ & $4.6 \times 10^{4}$ & $5.5 \times 10^{4}$ & $6.1 \times 10^{3}$ & $8.3 \times 10^{3}$ \\
HAB & $3.1 \times 10^{2}$ & $1.2 \times 10^{2}$ & $2.3 \times 10^{2}$ & $1.0 \times 10^{2}$ & $1.0 \times 10^{2}$ & $1.3 \times 10^{2}$ \\
\hline
\end{tabular}

OF: oxidized fine residues; NOF: non-oxidized fine residues; OC: oxidized coarse residues; NOC: non-oxidized coarse residues.

All bacterial groups were also detected in runoff waters, although in a lower number for SOB. On the other hand, the abundance of IOB was slightly higher in runoff waters than in tailings.

\subsection{Isolation and Identification of Acidophilic Bacteria}

The oxidation of ferrous ions was observed in the enrichment culture of FeTSB medium ( $\mathrm{pH}$ 2.5), reflecting the growth of acidophiles in this growth medium. Based on morphology, color, and growth rate, five strains were isolated from the Kettara tailings and runoff waters. The morphological characteristics of these strains are reported in Table 5. The isolates AMK1 and AMK5 were able to grow on FeTSB, TK, and 9KS medium, being classified as mixotrophic, whereas the isolates AMK2, AMK3, and AMK4 were only able to grow in FeTSB medium, being for that reason considered heterotrophic. 
Table 5. Phenotypic characteristics of bacterial strains.

\begin{tabular}{cccccccc}
\hline \multirow{2}{*}{ Strain } & \multirow{2}{*}{ Origin } & \multirow{2}{*}{ Gram } & \multirow{2}{*}{ Mobility } & \multicolumn{2}{c}{ Morphology of Colonies } & \\
\cline { 5 - 7 } & & & & Color & Shape & Border & Trophic Level \\
\hline AMK1 & RW & + & Not mobile & Rusty appearance & Circular & Regular & Mixotrophic \\
AMK2 & OF & + & Not mobile & Orange & Circular & Regular & Heterotrophic \\
AMK3 & OC & + & Not mobile & Orange & Stringy & Regular & Heterotrophic \\
AMK4 & NOF & + & Not mobile & Orange with colorless edges & Circular & Regular & Heterotrophic \\
AMK5 & NOC & + & Not mobile & Rusty appearance & Circular & Regular & Mixotrophic \\
\hline
\end{tabular}

OF: oxidized fine residues; NOF: non-oxidized fine residues; OC: oxidized coarse residues; NOC: non-oxidized coarse residues.

The partial sequences of the gene coding for the 16S rRNA of strains AMK1, AMK3, AMK4, and AMK5 were compared with sequences representative of the species Alicyclobacillus and Sulfobacillus (Figure 2). According to the phylogenetic tree, the strains AMK3 and AMK5 had a high similarity with the genus Alicyclobacillus sp., while the strains AMK1 and AMK4 were closely related to the Sulfobacillus species. It was not possible to identify strain AMK2.

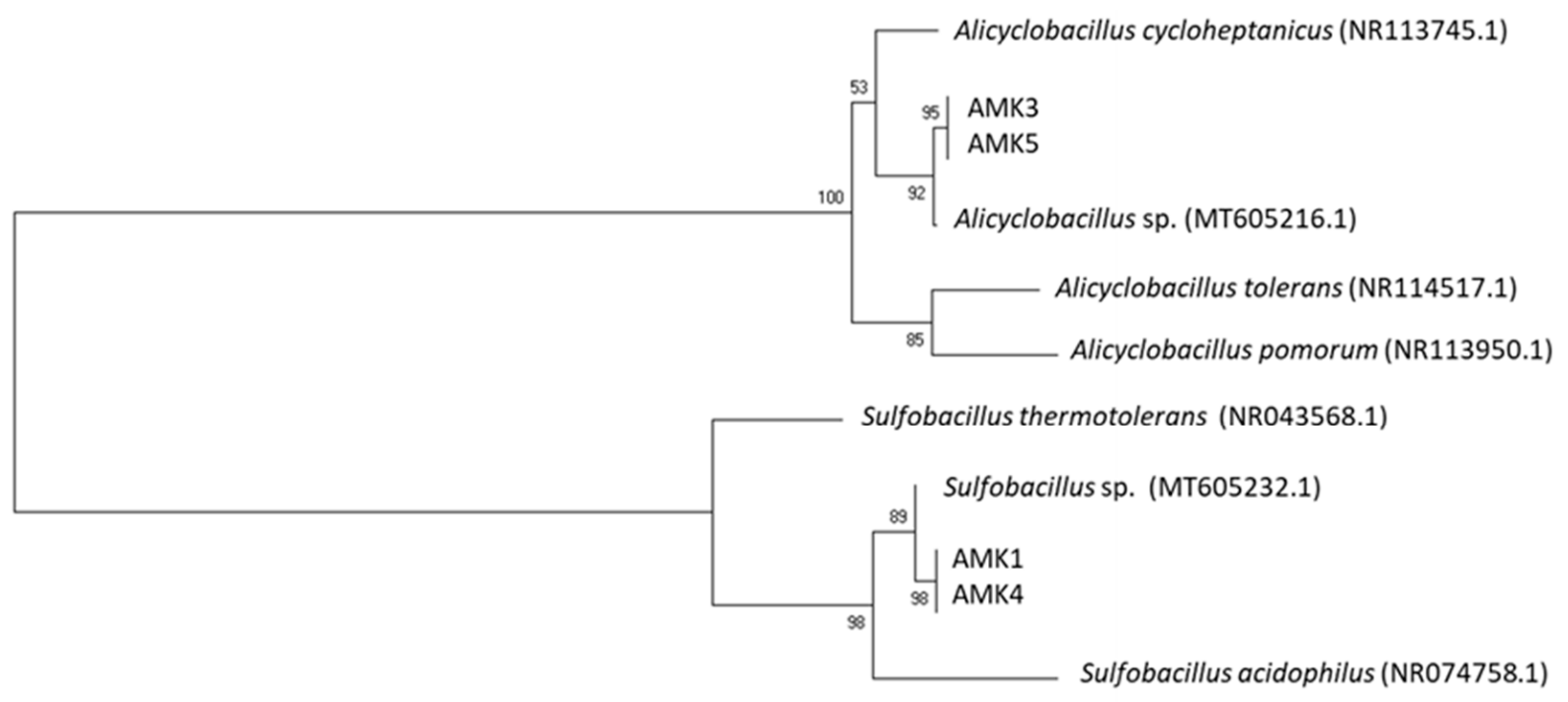

Figure 2. Maximum likelihood phylogenetic tree based on partial 16S rRNA sequences, showing the relationships between the sequences of representative strains and their closest phylogenetic relatives. Bootstrap values based on 1000 replications are indicated at the nodes.

\subsection{Metal Tolerance}

According to the results presented in Table 6 all strains showed a high metal tolerance. The strains AKM1 and AKM3 showed the highest tolerance to $\mathrm{Cu}$ with a maximum MIC value of $3177.30 \mathrm{mg} \mathrm{L}^{-1}$. The strains AKM1, AKM2, and AKM4 showed the best performance for $\mathrm{Zn}$ (MIC: 26,152-39,288 $\mathrm{mg} \mathrm{L}^{-1}$ ) and for Co (MIC: $2357.33 \mathrm{mg} \mathrm{L}^{-1}$ ). The strain AKM5 showed the lowest resistance to $\mathrm{Cu}\left(635.46 \mathrm{mg} \mathrm{L}^{-1}\right)$ and AKM2 to $\mathrm{Zn}\left(6538 \mathrm{mg} \mathrm{L}^{-1}\right)$ if compared to other strains, while AKM1 was the strain with a higher tolerance to all metals. 
Table 6. Minimum Inhibitory Concentration (MIC) for $\mathrm{Cu}, \mathrm{Zn}$ and $\mathrm{Co}$.

\begin{tabular}{lcccc}
\hline \multirow{2}{*}{ Strains } & Nearest Neighbor & \multicolumn{3}{c}{ MIC $\left(\mathbf{m g ~ L}^{-\mathbf{1}}\right)$} \\
\cline { 3 - 5 } & & $\mathbf{C u}$ & $\mathbf{Z n}$ & Co \\
\hline AKM1 & Sulfobacillus sp. & 3177.30 & 39,228 & 2357.33 \\
AKM2 & Not identified & 1588.65 & 6538 & 2357.33 \\
AKM3 & Alicyclobacillus sp. & 3177.30 & 26,152 & 1178.66 \\
AKM4 & Sulfobacillus sp. & 1588.65 & 39,228 & 2357.33 \\
AKM5 & Alicyclobacillus sp. & 635.46 & 13,076 & 1178.66 \\
\hline
\end{tabular}

\section{Discussion}

\subsection{Physical and Chemical Properties of Mine Tailings and Runoff Water}

Increasing knowledge of the physical, chemical, and microbiological properties of mine tailings, more specifically of sulfide residues, is crucial to assess their impact on ecosystems. It also provides valuable information to help the selection of methods suitable for remediation. The physical, chemical, and mineralogical characterization of Kettara mine tailings has already been the subject of several studies $[8,10,21,33]$. However, little is known about the acidophilic bacterial populations able to oxidize pyrrhotite and to generate AMD harbored in Kettara mine tailings. The present study is therefore a pioneer not only for the mines near Marrakesh but also in the entire country.

In this study, tailings showed lower $S$ levels $\left(20.8\right.$ to $\left.37.9 \mathrm{mg} \mathrm{g}^{-1}\right)$ than those reported by Hakkou et al. [21], where $S$ levels reached in some samples $145.0 \mathrm{mg} \mathrm{g}^{-1}$. Despite the low S content, tailings showed a very acid $\mathrm{pH}$ (average value of 2.7), suggesting that the increasing acid generation may be due to the lack of neutralizing capacity of the substrate [34,35]. It was also observed that a lower total $S$ content in coarse tailings if compared to fine suggested a depletion of this element over time in surface horizons. This is related to the particle sizes in the coarse tailings deposit which facilitates the access of water and oxygen to the fine particles which are more reactive thus leading to the oxidation of the sulfurous minerals of the waste rock and therefore a large production of sulfuric acid $[36,37]$.

The lowest $\mathrm{pH}$ values were recorded in non-oxidized samples of both types of tailings (fine and coarse), which can be explained by the drainage of acidic waters from the surface to the deeper zones of tailings. The Kettara mine tailings presented very low contents of TOC, TN, and available $\mathrm{P}$, constituting major limiting factors for the establishment and development of plants in these areas $[8,22,38,39]$. Indeed, low levels of organic matter and nutrients are commonly found in mine tailings [40-43], which may be explained by the fact that these wastes have resulted from a succession of ore processing stages [44].

The Kettara mine tailings showed very high concentrations of metals compared to the mean concentrations in the earth's crust [32]. Indeed, these high levels are a direct consequence of the processes of extraction and concentration of ores. Some metals $(\mathrm{Cr}, \mathrm{Co}$, $\mathrm{Zn}, \mathrm{Pb}$ and $\mathrm{Cu}$ ) are presented at lower concentrations in the oxidized layers than in the nonoxidized, indicating that these elements are leached from the upper areas of residues and then concentrated at the bottom. The pseudo-total concentrations of $\mathrm{Zn}, \mathrm{Pb}, \mathrm{As}$, and $\mathrm{Cu}$ in oxidized and non-oxidized residues were, in most cases, above the recommended levels for residential and parkland uses as defined by the Canadian Soil Quality Guidelines. For Cu and As, the concentrations registered were on average 12 and 9 times higher, respectively, than the recommended limits for industrial use, indicating that both elements were in very dangerous concentrations in tailings.

These results suggest that tailings from this mine are likely to generate AMD and corroborate previous studies carried out in this mining area $[8,10,21]$. The runoff water also showed very acidic $\mathrm{pH}$ values (2.19 to 2.23 ) and moderate electrical conductivity (6.81 to $\left.7.32 \mathrm{mS} \mathrm{cm}^{-1}\right)$, exceeding 8 times the limit allowed for irrigation water $\left(<0.75 \mathrm{mS} \mathrm{cm}^{-1}\right)$ [45]. The concentrations of $\mathrm{Cu}$ and $\mathrm{Zn}$ in these waters were also very high $\left(68.02-97.04 \mathrm{mg} \mathrm{L}^{-1}\right.$ and $25.42-45.81 \mathrm{mg} \mathrm{L}^{-1}$, respectively) and greatly exceeded the allowable limits settled 
by FAO [46] for irrigation water ( 0.2 and $2 \mathrm{mg} \mathrm{L}^{-1}$ for $\mathrm{Cu}$ and $\mathrm{Zn}$, respectively). The high concentrations of both metals in runoff waters were expected as both metals were part of the mineralogical composition of Kettara ore. In fact, these concentrations were similar to those found by El Khalil et al. [10].

\subsection{Microbiological Properties of Mine Tailings and Runoff Water}

In the present study, the acidophilic bacterial communities varied considerably between the oxidized and non-oxidized residues. Indeed, the highest MPN numbers for IOB, $\mathrm{SOB}$, and $\mathrm{HAB}$ were detected in the upper layers of tailings, which can be explained by the aerobic nature of these bacteria [47], suggesting that pyrite is likely oxidized by these bacterial communities. These results are in agreement with previous studies, where it was found that soil microbial communities changed with depth, the highest cell numbers being detected in oxidized zones [48-51]. Moreover, Bruneel et al. [16] also reported that bacterial diversity was slightly greater in the oxidized zones compared to the non-oxidized residues of the Kettara mine. Heterotrophic bacteria are likely to exist using the little organic carbon released by chemolithotrophs in sulfide mine wastes [52,53]. The abundance of IOB and SOB communities were quite high compared to the values obtained by Mendez et al. [50]. However, the number of IOB reported by [48] was 10 times higher than the values found in this study, which could be explained by differences in physical and chemical properties and by the clime of the region. The results obtained in this study clearly showed that the sulfide minerals in the Kettara tailings are oxidized by biological and chemical processes, explaining the AMD in this area, which have been reported by several authors $[8,10,21]$.

All bacterial strains isolated from tailings were acidophiles affiliated with previously identified genera in AMD ecosystems. The sequences of the 16S rRNA fragments of strains AMK3 and AMK5 showed a high similarity with heterotrophic and iron-oxidative bacteria classified in the genus Alicyclobacillus. Species of this genus, such as A. disulfidooxidans [54] and $A$. aeris [55], have often been identified in AMD. The strains AMK1 and AMK4 were closely related to Sulfobacillus, a genus that includes acidophilic mixotrophs with an optimal $\mathrm{pH}$ of 1.5-2.5 [56,57]. As mixotrophs, these species may switch between chemoheterotrophy and chemoautotrophy depending on the environmental conditions, which is an advantage in oligotrophic environments such as AMD [58,59]. In addition, many species belonging to these genera have also shown resistance to metals such as $\mathrm{Cu}, \mathrm{Ni}, \mathrm{Co}$, and $\mathrm{Zn}$ which are commonly found in these environments [60]. All strains isolated from Kettara tailings showed very high tolerance to metals, with MIC values of up to $3177.30 \mathrm{mg} \mathrm{L}^{-1}$ for Cu, $39,228 \mathrm{mg} \mathrm{L}^{-1}$ for $\mathrm{Zn}$ and $2357.33 \mathrm{mg} \mathrm{L}^{-1}$ for Co, corresponding respectively to $50 \mathrm{mM}$ of $\mathrm{Cu}, 600 \mathrm{mM}$ of $\mathrm{Zn}$, and $40 \mathrm{mM}$ of Co. These concentrations were 2- to 3-fold lower than those reported by Johnson et al. [61] for $\mathrm{Cu}$ and $\mathrm{Co}(130$ and $120 \mathrm{mM})$ and 2-fold higher for $\mathrm{Zn}(360 \mathrm{mM})$ in a strain of Sulfobacillus benefaciens isolated from bioleaching operations for sulfide ores. The high metal tolerance of these indigenous bacteria is attributed to the very high metal concentrations in mining wastes $\left(0.650-1.89 \mathrm{mg} \mathrm{Cu} \mathrm{g}^{-1}, 0.05-0.57 \mathrm{mg} \mathrm{Zn} \mathrm{g}^{-1}\right.$ and $0.01-0.06 \mathrm{mg} \mathrm{Co} \mathrm{g}^{-1}$ ) that largely exceed the average levels present in the earth's crust (0.025 $\mathrm{mg} \mathrm{Cu} \mathrm{g}^{-1}, 0.065 \mathrm{mg} \mathrm{Zn} \mathrm{g}^{-1}$ and $\left.0.024 \mathrm{mg} \mathrm{Co} \mathrm{g}^{-1}\right)$ [42]. Exposure to high concentrations of metals is therefore likely to exert selective pressure on bacterial communities favoring the emergence of highly metal-tolerant acidophilic bacteria [62]. Indeed, several authors have reported that bacteria isolated from mining areas that are highly contaminated are shown to exhibit high tolerance to different metals $[63,64]$.

\section{Conclusions}

The Kettara tailings contain significant amounts of potentially toxic metal-rich sulfide minerals which can pose serious environmental threats. The physical, chemical, and microbiological parameters suggested the existence of chemical and biological processes responsible for the oxidation of sulfide minerals. This may cause the solubilization of metallic elements presented in millions of tons of mining waste rock, resulting in very acidic and highly metal contaminated runoff waters, as observed in this study. 
These highly acidic, high-metal, and nutrient-deprived tailings harbor chemolithoautotrophic and heterotrophic acidophilic bacteria capable of oxidizing iron and sulfur compounds. The higher abundance of these bacterial communities is correlated with a high proportion of the oxidation of pyrite in the upper layers of tailings. This suggested that the oxidation of sulfide minerals is strongly influenced by the microbial activity in Kettara mine tailings.

Plants are not able to grow in mining wastes due to their inhospitable physical and chemical properties. This results in large areas devoid of vegetation cover and directly exposed to erosion, leading to a consequent contamination of the surrounding environment. Therefore, it is necessary to improve the quality of these wastes in order to facilitate the establishment of plants and to accelerate the recovery of these ecosystems. According to previous studies the combined use of chemical and biological remediation techniques is very often a suitable strategy to accelerate and increase the success of reclamation of mining areas either by enhancing tailings fertility or preventing AMD, rendering a viable approach for the remediation of the Kettara mine.

Author Contributions: L.B. designed the study, performed the experiments, and wrote the manuscript. S.I.A.P. carried out the DNA extraction and treatment of acidophilic bacteria sequences, wrote and revised the manuscript. S.L. contributed to the analysis of tailings and interpretation of the results. P.M.L.C. provided critical feedback and helped shape the final manuscript. A.B. conceived the original idea and oversaw overall direction and planning of this work. All authors have read and agreed to the published version of the manuscript.

Funding: This study was financially supported by the Convention de coopération CNRST-Morocco/FCTPortugal, Centre National de Recherche Scientifique et Techniques [grant no. PPR 22/2015] and the project Phy2Sudoe-Advancing in the application of innovative phytomanagement strategies in contaminated areas of the SUDOE space (SOE4/P5/E1021), funded by the European Regional Development Fund (European Commission) through the V Interreg Sudoe Programme.

Institutional Review Board Statement: Not applicable.

Informed Consent Statement: Not applicable.

Data Availability Statement: All data generated or analyzed during this study are included in this published article.

Acknowledgments: The authors would like to thank the scientific collaboration of Fundação Ciência e Tecnologia (FCT) project UIDB/50016/2020. The authors would also thank to T. Hogg for correcting the English of this paper.

Conflicts of Interest: The authors declare that they have no known conflict of interest or personal relationships that could have appeared to influence the work reported in this paper.

\section{References}

1. Adhikari, K.; Hartemink, A.E. Linking soils to ecosystem services-A global review. Geoderma 2016, 262, 101-111. [CrossRef]

2. Kihara, J.; Bolo, P.; Kinyua, M.; Nyawira, S.S.; Sommer, R. Soil health and ecosystem services: Lessons from sub-Sahara Africa (SSA). Geoderma 2020, 370, 114342. [CrossRef]

3. FAO. Soil Pollution: A Hidden Reality; FAO: Rome, Italy, 2018; p. 142.

4. Babi, K.; Asselin, H.; Benzaazoua, M. Stakeholders' perceptions of sustainable mining in Morocco: A case study of the abandoned Kettara mine. Extr. Ind. Soc. 2016, 3, 185-192. [CrossRef]

5. Sonter, L.J.; Ali, S.H.; Watson, J.E.M. Mining and biodiversity: Key issues and research needs in conservation science. Proc. R. Soc. B 2018, 285, 20181926. [CrossRef]

6. Sonter, L.J.; Dade, M.C.; Watson, J.E.M.; Valenta, R.K. Renewable energy production will exacerbate mining threats to biodiversity. Nat. Commun. 2020, 11, 1-6. [CrossRef]

7. Clapcott, J.E.; Goodwin, E.O.; Harding, J.S. Identifying catchment-scale predictors of coal mining impacts on New Zealand stream communities. Environ. Manag. 2016, 57, 711-721. [CrossRef]

8. Boularbah, A.; Schwartz, C.; Bitton, G.; Morel, J.L. Heavy metal contamination from mining sites in South Morocco: 1. Use of a biotest to assess metal toxicity of tailings and soils. Chemosphere 2006, 63, 802-810. [CrossRef]

9. Boularbah, A.; Schwartz, C.; Bitton, G.; Aboudrar, W.; Ouhammou, A.; Morel, J.L. Heavy metal contamination from mining sites in South Morocco: 2. Assessment of metal accumulation and toxicity in plants. Chemosphere 2006, 63, 811-817. [CrossRef] 
10. El Khalil, H.E.; Hamiani, O.E.; Bitton, G.; Ouazzani, N.; Boularbah, A. Heavy metal contamination from mining sites in South Morocco: Monitoring metal content and toxicity of soil runoff and groundwater. Environ. Monit. Assess. 2008, 136, 147-160. [CrossRef]

11. El Hamiani, O.; El Khalil, H.; Lounate, K.; Sirguey, C.; Hafidi, M.; Bitton, G.; Schwartz, C.; Boularbah, A. Toxicity assessment of garden soils in the vicinity of mining areas in Southern Morocco. J. Hazard. Mater. 2010, 177, 755-761. [CrossRef]

12. Benidire, L.; Benidire, L.; Boularbah, A. Impacts of mining activities on soil properties: Case studies from Morocco mine sites. Soil Sci. Anпu. 2021, 71, 395-407.

13. Yadollahi, A.; Abdollahi, H.; Ardejani, F.D.; Mirmohammadi, M.; Magdouli, S. Bio-oxidation behavior of pyrite, marcasite, pyrrhotite, and arsenopyrite by sulfur-and iron-oxidizing acidophiles. Bioresour. Technol. Rep. 2021, 15, 100699. [CrossRef]

14. Skousen, J.G.; Ziemkiewicz, P.F.; McDonald, L.M. Acid mine drainage formation, control and treatment: Approaches and strategies. Extr. Ind. Soc. 2019, 6, 241-249. [CrossRef]

15. Rambabu, K.; Banat, F.; Pham, Q.M.; Ho, S.-H.; Ren, N.-Q.; Show, P.L. Biological remediation of acid mine drainage: Review of past trends and current outlook. Environ. Sci. Technol. 2020, 2, 100024. [CrossRef]

16. Bruneel, O.; Mghazli, N.; Hakkou, R.; Dahmani, I.; Maltouf, A.F.; Sbabou, L. In-depth characterization of bacterial and archaeal communities present in the abandoned Kettara pyrrhotite mine tailings (Morocco). Extremophiles 2017, 21, 671-685. [CrossRef]

17. Panda, S.; Mishra, S.; Akcil, A. Bioremediation of acidic mine effluents and the role of sulfidogenic biosystems: A mini-review. Euro-Mediterr. J. Environ. Integr. 2016, 1, 8. [CrossRef]

18. Narayanan, M.; Devarajan, N.; He, Z.; Kandasamy, S.; Ashokkumar, V.; Raja, R.; Carvalho, I.S. Assessment of microbial diversity and enumeration of metal tolerant autochthonous bacteria from tailings of magnesite and bauxite mines. Mater. Today Proc. 2020, 33, 4391-4401. [CrossRef]

19. Gupta, A.; Sar, P. Characterization and application of an anaerobic, iron and sulfate reducing bacterial culture in enhanced bioremediation of acid mine drainage impacted soil. J. Environ. Sci. Health 2020, 55, 464-482. [CrossRef]

20. Fashola, M.O.; Ngole-Jeme, V.M.; Babalola, O.O. Heavy metal pollution from gold mines: Environmental effects and bacterial strategies for resistance. Int. J. Environ. Res. Public Health. 2016, 13, 1047. [CrossRef]

21. Hakkou, R.; Benzaazoua, M.; Bussière, B. Acid mine drainage at the abandoned Kettara Mine (Morocco): 1. Environmental Characterization. Mine Water Environ. 2008, 27, 145-159. [CrossRef]

22. Midhat, L.; Ouazzani, N.; Esshaimi, M.; Ouhammou, A.; Mandi, L. Assessment of heavy metals accumulation by spontaneous vegetation: Screening for new accumulator plant species grown in Kettara mine-Marrakech, Southern Morocco. Int. J. Phytorem. 2017, 19, 191-198. [CrossRef] [PubMed]

23. Blakemore, L.C.; Searle, P.L.; Daly, B.K. Methods for Chemical Analysis of Soils New Zealand Soil Bureau Report 10A; Government printer; Department of Scientific and Industrial Research: Wellington, New Zealand, 1972.

24. Olsen, S.R.; Sommers, L.E. Phosphorus. In Methods of Soil Analysis Part 2, 2nd ed.; Page, A.L., Miller, R.H., Keeney, D.R., Eds.; Agronomy Society of America: Madison, WI, USA, 1982; pp. 403-430.

25. Potts, P.J. A Handbook of Silicate Rock Analysis; B1ackie \& Sons, Ltd.: London, UK, 1987.

26. Alexander, M. Most probable number method for microbial populations. In Methods of Soil Analysis. Part 2. Chemical and Microbiological Properties; Black, C.A., Ed.; American Society of Agronomy: Madison, WI, USA, 1965; pp. $1467-1472$.

27. Tuovinen, O.H.; Kelly, D.P. Studies on the growth of Thiobacillus ferrooxidans. Arch. Microbiol. 1973, 88, 285-298. [CrossRef]

28. Silverman, M.P.; Lundgren, D.G. Studies on the chemoautotrophic iron bacterium Ferrobacillus ferrooxidans: I. An improved medium and a harvesting procedure for securing high cell yields. J. Bacteriol. 1959, 77, 642. [CrossRef] [PubMed]

29. Singh, S.; Panda, S.; Mishra, S.; Pradhan, N.; Mohanty, R.C.; Sukla, L.B. Evaluation of microbial population and attachment study during bio-heap leaching at Malanjkhand copper project. Int. J. Environ. Waste Manag. 2013, 11, 75-86. [CrossRef]

30. Johnson, D.B.; Macvicar, J.H.; Rolfe, S. A new solid medium for the isolation and enumeration of Thiobacillus ferrooxidans and acidophilic heterotrophic bacteria. J. Microbiol. Methods. 1987, 7, 9-18. [CrossRef]

31. Tamura, K.; Stecher, G.; Peterson, D.; Filipski, A.; Kumar, S. MEGA6: Molecular evolutionary genetics analysis version 6.0. Mol. Biol. Evol. 2013, 30, 2725-2729. [CrossRef] [PubMed]

32. Wedepohl, K.H. The composition of the continental crust. Geochim. Cosmochim. Acta 1995, 59, 1217-1232. [CrossRef]

33. Hakkou, R.; Benzaazoua, M.; Bussière, B. Laboratory evaluation of the use of alkaline phosphate wastes for the control of acidic mine drainage. Mine Water Environ. 2009, 28, 206. [CrossRef]

34. Dave, S.R.; Tipre, D.R. Coal mine drainage pollution and its remediation. In Microorganisms in Environmental Management; Satyanarayana, T., Johri, B.D., Eds.; Springer: Dordrecht, The Netherlands, 2012; pp. 719-743.

35. Pozo-Antonio, S.; Puente-Luna, I.; Lagüela-López, S.; Veiga-Ríos, M. Techniques to correct and prevent acid mine drainage: A review. Dyna 2014, 81, 73-80. [CrossRef]

36. Ferguson, K.D.; Erickson, P.M. Pre-mine prediction of acid mine drainage. In Environmental Management of Solid Waste; Salomons, W., Förstner, U., Eds.; Springer: Berlin, Germany, 1988; pp. 24-43.

37. Lottermoser, B.G. Mine Wastes; Springer: Berlin/Heidelberg, Germany, 2010.

38. El Faiz, A.; Duponnois, R.; Winterton, P.; Ouhammou, A.; Meddich, A.; Boularbah, A.; Hafidi, M. Effect of different amendments on growing of Canna indica L. inoculated with AMF on mining substrate. Int. J. Phytorem. 2015, 17, 503-513. [CrossRef] 
39. Ouaryi, A.; Boularbah, A.; Sanguin, H.; Hafidi, M.; Baudoin, E.; Ouahmane, L.; Le Roux, C.; Galiana, A.; Prin, Y.; Duponnois, R. High potential of symbiotic interactions between native mycorrhizal fungi and the exotic tree Eucalyptus camaldulensis for phytostabilization of metal-contaminated arid soils. Int. J. Phytorem. 2016, 18, 41-47. [CrossRef] [PubMed]

40. Gil-Loaiza, J.; White, S.A.; Root, R.A.; Solís-Dominguez, F.A.; Hammond, C.M.; Chorover, J.; Maier, R.M. Phytostabilization of mine tailings using compost-assisted direct planting: Translating greenhouse results to the field. Sci. Total Environ. 2016, 565, 451-461. [CrossRef] [PubMed]

41. Benidire, L.; Pereira, S.I.A.; Aboudrar, W.; Hafidi, M.; Castro, P.M.L.; Boularbah, A. Remediation of metal-contaminated mine tailings by the application of organic and mineral amendments. J. Soils Sediments 2022, 22, 482-495. [CrossRef]

42. Benidire, L.; Madline, A.; Pereira, S.I.A.; Castro, P.M.L.; Boularbah, A. Synergistic effect of organo-mineral amendments and plant growth-promoting rhizobacteria (PGPR) on the establishment of vegetation cover and amelioration of mine tailings. Chemosphere 2021, 262, 127803. [CrossRef]

43. Gomes, A.R.; Antão, A.; Santos, A.G.P.; Lacerda, T.J.; Mirelli, B.M.; Isla, A.S.; Alvarenga, S.; Santos, C.H.; Rigobelo, E.C.; Scotti, M.R. Rehabilitation of a riparian site contaminated by tailings from the Fundão Dam, Brazil, using different remediation. Environ. Toxicol. Chem. 2021, 40, 2359-2373. [CrossRef]

44. El Hachimi, M.L.; Bouabdli, A.; Fekhaoui, M. Les rejets miniers de traitement: Caractérisation, capacité polluante et impacts environnementaux, mine Zeïda, mine Mibladen, Haute Moulouya (Maroc). Environ. Sci. 2013, 323, 32-42. [CrossRef]

45. Burger, F.; Celkova, A. Salinity and sodicity hazard in water flow processes in the soil. Plant Soil Environ. 2003, 49, 314-320. [CrossRef]

46. FAO. Water Quality for Agriculture. Paper No. 29 (Rev. 1); UNESCO Publication: Rome, Italy, 1985; p. 96.

47. Johnson, D.B. Geomicrobiology of extremely acidic subsurface environments. FEMS Microbiol. Ecol. 2012, 81, 2-12. [CrossRef]

48. Kock, D.; Schippers, A. Geomicrobiological investigation of two different mine waste tailings generating acid mine drainage. Hydrometallurgy 2006, 83, 167-175. [CrossRef]

49. Kock, D.; Schippers, A. Quantitative microbial community analysis of three different sulfidic mine tailing dumps generating acid mine drainage. Appl. Environ. Microbiol. 2008, 74, 5211-5219. [CrossRef]

50. Mendez, M.O.; Neilson, J.W.; Maier, R.M. Characterization of a bacterial community in an abandoned semiarid lead-zinc mine tailing site. Appl. Environ. Microbiol. 2008, 74, 3899-3907. [CrossRef] [PubMed]

51. Korehi, H.; Blothe, M.; Sitnikova, M.A.; Dold, B.; Schippers, A. Metal mobilization by iron-and sulfur-oxidizing bacteria in a multiple extreme mine tailings in the Atacama Desert, Chile. Environ. Sci. Technol. 2013, 47, 2189-2196. [CrossRef] [PubMed]

52. Schippers, A.; Breuker, A.; Blazejak, A.; Bosecker, K.; Kock, D.; Wright, T.L. The biogeochemistry and microbiology of sulfidic mine waste and bioleaching dumps and heaps, and novel Fe (II)-oxidizing bacteria. Hydrometallurgy 2010, 104, 342-350. [CrossRef]

53. Joe, S.J.; Suto, K.; Inoie, C.; Chida, T. Isolation and characterization of acidophilic heterotrophic iron-oxidizing bacterium from enrichment culture obtained from acid mine drainage treatment plant. J. Biosci. Bioeng. 2007, 104, 117-123. [CrossRef] [PubMed]

54. Guo, Z.; Megharaj, M.; Beer, M.; Ming, H.; Rahman, M.M.; Wu, W.; Naidu, R. Heavy metal impact on bacterial biomass based on DNA analyses and uptake by wild plants in the abandoned copper mine soils. Bioresour. Technol. 2009, 100, 3831-3836. [CrossRef] [PubMed]

55. Dufresne, S.; Bousquet, J.; Boissinot, M.; Guay, R. Sulfobacillus disulfidooxidans sp. nov., a new acidophilic, disulfide-oxidizing, gram-positive, spore-forming bacterium. Int. J. Syst. Evol. Microbiol. 1996, 46, 1056-1064. [CrossRef] [PubMed]

56. Bogdanova, T.I.; Tsaplina, I.A.; Kondrat'eva, T.F.; Duda, V.I.; Suzina, N.E.; Melamud, V.S.; Tourova, T.P.; Karavaiko, G.I. Sulfobacillus thermotolerans sp. nov., a thermotolerant, chemolithotrophic bacterium. Int. J. Syst. Evol. Microbiol. 2006, 56, 1039-1042. [CrossRef]

57. Baker, B.J.; Banfield, J.F. Microbial communities in acid mine drainage. FEMS Microbiol. Ecol. 2003, 44, 139-152. [CrossRef]

58. Okibe, N.; Johnson, D.B. Biooxidation of pyrite by defined mixed cultures of moderately thermophilic acidophiles in pH-controlled bioreactors: Significance of microbial interactions. Biotechnol. Bioeng. 2004, 87, 574-583. [CrossRef]

59. Hao, C.; Wang, L.; Dong, H.; Zhang, H. Succession of acidophilic bacterial community during bio-oxidation of refractory gold-containing sulfides. Geomicrobiol. J. 2010, 27, 683-691. [CrossRef]

60. Watling, H.R.; Perrot, F.A.; Shiers, D.W. Comparison of selected characteristics of Sulfobacillus species and review of their occurrence in acidic and bioleaching environments. Hydrometallurgy 2008, 93, 57-65. [CrossRef]

61. Johnson, D.B.; Joulian, C.; d'Hugues, P.; Hallberg, K.B. Sulfobacillus benefaciens sp. nov., an acidophilic facultative anaerobic Firmicute isolated from mineral bioleaching operations. Extremophiles 2008, 12, 789-798. [CrossRef]

62. Jeremic, S.; Beškoski, V.P.; Djokic, L.; Vasiljevic, B.; Vrvić, M.M.; Avdalović, J.; Gojgić, C.G.; Beškoski, L.S.; Nikodinovic-Runic, J. Interactions of the metal tolerant heterotrophic microorganisms and iron oxidizing autotrophic bacteria from sulphidic mine environment during bioleaching experiments. J. Environ. Manag. 2016, 172, 151-161. [CrossRef] [PubMed]

63. Benidire, L.; Pereira, S.I.A.; Castro, P.M.L.; Boularbah, A. Assessment of plant growth promoting bacterial populations in the rhizosphere of metallophytes from the Kettara mine, Marrakech. Environ. Sci. Pollut. Res. 2016, 23, 21751-21765. [CrossRef] [PubMed]

64. Fashola, M.O.; Ngole-Jeme, V.M.; Babalola, O.O. Physicochemical properties, heavy metals, and metal-tolerant bacteria profiles of abandoned gold mine tailings in Krugersdorp, South Africa. Can. J. Soil Sci. 2020, 100, 217-233. [CrossRef] 